\title{
Antioxidant and Neuroprotective Activities of the Mesocarp of Raphia hookeri Fruit against Aluminum Chloride-Induced Neurotoxicity in Rats
}

\author{
Hermine Tsafack Doungue ${ }^{1}$, Anne Pascale Nouemsi Kengne ${ }^{1,2^{*}}$, Hilaire Marcaire Womeni1 \\ ${ }^{1}$ Research Unit of Biochemistry, Medicinal Plants, Food Sciences and Nutrition, Department of Biochemistry, University of \\ Dschang, Dschang, Cameroon \\ ${ }^{2}$ Laboratory of Nutrition and Nutritional Biochemistry, Department of Biochemistry, University of Yaounde I, Yaounde, \\ Cameroon \\ Email: dounguehermine@yahoo.fr, ‘kengneannepas@yahoo.fr, womeni@yahoo.fr
}

How to cite this paper: Doungue, H.T., Kengne, A.P.N. and Womeni, H.M. (2020) Antioxidant and Neuroprotective Activities of the Mesocarp of Raphia hookeri Fruit against Aluminum Chloride-Induced Neurotoxicity in Rats. Food and Nutrition Sciences, 11, 396-415.

https://doi.org/10.4236/fns.2020.115029

Received: March 27, 2020

Accepted: May 17, 2020

Published: May 20, 2020

Copyright $\odot 2020$ by author(s) and Scientific Research Publishing Inc. This work is licensed under the Creative Commons Attribution International License (CC BY 4.0).

http://creativecommons.org/licenses/by/4.0/

(c) (i) Open Access

\begin{abstract}
This work aims to evaluate the antioxidant and protective effect of Raphia hookeri $(R h)$ fruit extracts and powders against aluminum induced neurotoxicity in rats. Extracts and powder were prepared using fruit mesocarp. Phytochemical contents (phenolic content and flavonoïd) and antioxidant in vitro activity were evaluated through the DPPH radical scavenging capacity, the ability to reduce ferric ion and Hydroxyl radical scavenging ability. The neurocognitive dysfunction, the activity of acetylcholinesterase (AChE) and activities of antioxidant in vivo indices were evaluated in the plasma, liver and brain of aluminum chloride $\left(\mathrm{AlCl}_{3}\right)$ induced neurotoxicity in rats. The highest total phenolic (76.34 mg Eq AG/g of extract), flavonoïds' contents (13.32 $\mathrm{mg} \mathrm{Eq} \mathrm{CAT/g}$ of extract), the best DPPH scavenging activity and the ability to reduce ferric ion $\left(\mathrm{Fe}^{3+}\right)$ were obtained with aqueous extract. The administration of aqueous extract (200 and $400 \mathrm{~g} / \mathrm{kg} \mathrm{bw})$ and powder (5\% and $10 \%)$ during 28 days resulted in a significant decrease $(P<0.05)$ of the time use to find platform and the increase of the acquisition speed of food in rats. Also the evaluation of some biochemical parameters shows the decrease of malondialdehyde, nitric oxide and acetylcholine esterase activity and the increase of total protein level, catalase activities (CAT), superoxide dismutase (SOD) and glutathione level in plasma, liver and brain compared to the positive control group (PC). The best activities were obtained with groups ARh400 and Rh10\%. Treatment with aqueous extract and powder of Rh mesocarp ameliorated neurobehavioral changes by enhancing antioxidant activities, cognitive functions. Therefore $R h$ would protect oxidative damage and
\end{abstract}


preserve neurone functions.

\section{Keywords}

Raphia hookeri, Phenolic Compounds, Rats, Aluminium Chloride, Antioxidant, Neuroprotective Effect

\section{Introduction}

Aerobic cellular metabolism continuously produces reactive oxygen species (ROS) with concomitant potential for mutagenic and oncogenic effects. The imbalance between ROS and antioxidants induces oxidative stress. This oxidative stress is implicated in several degenerative disorders such as: pathogenesis in inflammatory, partial ischemia, metabolic and denatured cranial nerve disease [1]. The increase and the oldness of the population are concomitant for the incidence of age-related diseases such as neurodegeneration [2]. Brain tissues are also highly susceptible to oxidative damage, probably because of its high oxygen consumption rate $(20 \%)$, the presence of abundant polyunsaturated fatty acids in cell membranes, high iron (Fe) content, and low enzymatic antioxidants' activities [3]. Aluminum is one of the well-known environmental heavy metal agents that affect the brain development, it can induce oxidative damage through multiple mechanisms such as binding to negative charged brain phospholipids, which contain polyunsaturated fatty acids and are easily attacked by reactive oxygen species (ROS) [4]. Aluminum has the potential to be neurotoxic in humans and animals, and is present in many manufactured foods and medicines [5].

Central nervous system cells are able to combat oxidative stress using some limited resources: vitamins, bioactive molecules, lipoic acid, antioxidant enzymes and redox sensitive protein transcriptional factors [2]. However, this defense system can be activated/modulated by nutritional antioxidants such as polyphenols [3]. Epidemiological evidence indicates that antioxidant supplementation may provide neuroprotection against age-related neurodegenerative disorders [6]. Flavonoïds have been reported to have substantial neuroprotective activity [3]. These effects have been attributed to their general free radical trapping capacity, antioxidant activity on neurons, but they also intervene in multiple biological processes, such as iron chelation, activation of survival genes, cell signaling pathways and regulation of mitochondrial function [1] [2].

These observations prompted us to focus on Raphia hookeri $(R h)$ which is the largest palm tree in Africa and is commonly found in the tropical rainforest [7]. All the parts of this plant are largely used. The sap from the stem ferments rapidly into palm wine and the raw fruit is sometimes used to flavor food. In Nigeria boiled fruits are eaten and the oily mesocarp is used in traditional medicine for its laxative and stomachal properties [8]. The mesocarp of $R h$ is rich in bioactive compounds such as vitamin E, niacin, alkaloid, saponins, flavonoïd and 
phenols [5]. However, the neuroprotective effects of $R h$ fruit are not well known. Bioactive compounds contained in $R h$ fruit may also have some neuroprotective effects. This leads us to evaluate antioxidant and neuroprotective properties of Raphia hookeri powder and aqueous extract in a model of Aluminum chloride inducing neurotoxicity by using rats.

\section{Methods}

\subsection{Plant Material}

Fresh mature Raphia hookeri fruits were harvested from swampy field of the West region of Cameroon from April to June 2018.

\subsection{Methods}

\subsubsection{Extraction of Natural Antioxidants}

Polyphenols were extracted from plant materials using the maceration method, as previously described [9]. The fresh fruits were cleaned and peeled. The mesocarp was cut into small pieces using a rustproof knife and dried in oven at $45^{\circ} \mathrm{C}$ for 48 hours. The dried mesocarp was grinded in a blender machine (Moulinex) and sieved (Diameter of pore: $1 \mathrm{~mm}$ ). The formulation (Rh5\% et $\mathrm{Rh} 10 \%)$ was done as follows: Rh $5 \%$ was prepared using $95 \mathrm{~g}$ of food staple $+5 \mathrm{~g}$ of $R h$ powder and $R h 10 \%$ was prepared $90 \mathrm{~g}$ of food staple $+10 \mathrm{~g}$ of $R h$ powder. The food staple was composed as follows: corn flour (77.8\%), fish flour (20\%), bone flour $(0.1 \%)$, palm olein (1\%), vitamins (0.1\%), and salt (1\%). $20 \mathrm{~g}$ of Rh powder was extracted into $200 \mathrm{ml}$ of water and the mixture was regularly shaken during the extraction. $20 \mathrm{~g}$ of powder was extracted into $200 \mathrm{ml}$ of ethanol, water and hydroethanolic (20/80) solvent respectively. The mixture was regularly subjected to shaking during the extraction. After 48 hours of maceration, the mixture was filtered with a Wathman $\mathrm{N}^{\circ} 1$ filter paper and the filtrates were subjected to evaporation at $45^{\circ} \mathrm{C}$. The dried extracts were stored at $4{ }^{\circ} \mathrm{C}$ for further analysis.

\subsubsection{Determination of Total Phenol and Flavonoïds Content of $R \boldsymbol{h}$ Mesocarp Extract}

The total phenolic content of $R h$ mesocarp was determined using the Folin-Ciocalteu colorimetric method, as previously described [10].

Aluminium chloride method was used for flavonoïd determination using the method described by [11].

\subsubsection{Evaluation of Antioxidant Activity in-Vitro $R h$ Extract}

$>$ The radical scavenging ability of the extracts was determined according to the method as previously described [12] and the efficient concentration 50 (EC50) was determined.

$>$ The ability of the extracts tested to reduce ferric iron $\left(\mathrm{Fe}^{3+}\right)$ present in the $\mathrm{K}_{3} \mathrm{Fe}(\mathrm{CN})_{6}$ complex to ferrous iron $\left(\mathrm{Fe}^{2+}\right)$ was determined as previously described [13].

The hydroxyl radical scavenging capacity of the mesocarp extracts was eva- 
luated by the method as previously described [14].

\subsection{In Vivo Antioxidant and Neuroprotective Effect of $\boldsymbol{R} h$ Aqueous Extract and Powder on Aluminum Chloride Induced Neurotoxicity}

\section{Experimental Animals and Induction of Neurotoxicity}

Seven groups of six animals each weighing between 200 and $230 \mathrm{~g}$ were obtained from the Department Animal Centre and allowed to be accustomed to the new environment for 1 week. They were maintained in accordance with the guidelines as previously described [15]. Animals were individually housed under controlled temperature $\left(25^{\circ} \mathrm{C}\right),(12 \mathrm{~h}$ light $/ 12 \mathrm{~h}$ dark cycle) and had free access to water and diet. $\mathrm{AlCl}_{3}(4.2 \mathrm{mg} / \mathrm{kg} /$ intraperitonial $)$ was administered daily to all groups except the normal animal group for 28 successive days. The dose of $\mathrm{AlCl}_{3}$ was selected on the basis of the literature reports [15]. Aqueous extract (200, and $400 \mathrm{mg} / \mathrm{kg}$ body weight) and powder (5\% and $10 \%)$ of $R h$ were administered daily through oral route to different groups of rats for 28 consecutive days. Otherwise, positive control group received $200 \mathrm{mg}$ vitamin C (which is a standard antioxidant) per Kg body weight and negative control group received no treatment during the administration of aluminum chloride.

\subsection{Assessment of Animal Behavior during Treatment}

\subsubsection{Arm Labyrinth Procedure}

The 8-arm radial labyrinth was developed for rats [16]. Animals were deprived of food for 24 hours. An animal was placed on the center of the device to explore the maze for 5 minutes a day. Rats were trained to find the food reward at the distal ends of eight arms during these $5 \mathrm{~min}$. Each session lasts until all 8 arms are seized. The 4 arms filled with rewards were always the same, in order to teach the animal to find the food only in these 4 arms for $5 \mathrm{~min}$. The behavior of the animal for $5 \mathrm{~min}$ was recorded by a video camera. To prevent odors, the maze was cleaned between the animals.

\section{Acquisition speed $=($ number of Rewards $) /($ time taken $)$}

\subsubsection{Morris Aquatic Maze Procedure (Water Maze)}

The Morris Protocol [17] is to locate the invisible submerged platform whose position remains unchanged during 3 consecutive days. Each rat underwent a daily session of 3 trials separated by a $5 \mathrm{~min}$ period during which the animal was placed in its cage. At each test, the animal was deposited in the water facing the wall from a determined starting point which varies from test to test. The test ends when the rat has reached the platform, or when 60 seconds have elapsed. If the rat did not find the platform during the 60 seconds of the test, it was guided by the experimenter to the platform. Once the animal was on the platform, it was left for 10 seconds before the experimenter presented it with a metal transport grid. The main variables identified were the platform hit latency (maximum: 60 seconds) and the distance travelled during the journey. 


\subsection{Tissue Preparation for Biochemical Estimation}

After 28 days of treatment, animals were sacrificed under anesthesia using steam chloroform. Blood was collected in EDTA tubes. Immediately after collection, the liver and brains were removed carefully. The brain was homogenized in ice-cold phosphate buffer Ph 7.4. Plasma was prepared from the collected blood and homogenates from the liver and brain.

\section{Biochemical Assessments}

MDA was evaluated as previously described [18].

$>$ Total protein determination was evaluated as previously described [19].

> Glutathione was performed according to the method as previously described [20].

Acetylcholinesterase activity was assessed according to the method as previously described [21].

Assessment of catalase activity was assayed according to the method as previously described [22].

The activity of superoxide dismutase (SOD) was assayed according to the method as previously described [23].

Nitric oxide (NO) assessment was performed according to the method as previously described [24].

\section{Statistical analysis}

Results obtained in the present study were subjected to one-way analysis of variance (ANOVA) with turkey test using Minitab version 17.0 to evaluate the statistical significance of the data. A probability value at $P<0.05$ was considered statistically significant.

\section{Results}

\subsection{Total Phenols and Flavonoïds Content of Raphia hookeri Mesocarp Extracts}

The total phenolic and flavonoïd content of different extracts of Raphia hookeri mesocarp are presented in Table 1 . Total phenol contents differ significantly between 50.83 and $76.34 \mathrm{mg}$ Eq AG/g of extract and the aqueous extract of $R h$ present the highest total phenolic content which is $76.34 \mathrm{mg} \mathrm{Eq} \mathrm{cat/g}$ of extract. The flavonoïd content differ significantly between 5.64 and $13.32 \mathrm{mg} \mathrm{Eq} \mathrm{CAT/g}$

Table 1. Total Phenolic and flavonoïd content of Raphia hookeri mesocarp.

\begin{tabular}{ccc}
\hline extracts & w $($ mg Eq GAE/g of extract $)$ & w $(m g$ Eq CAT/g of extract $)$ \\
\hline AR.h & $76.34 \pm 0.04^{\mathrm{a}}$ & $13.32 \pm 0.00^{\mathrm{a}}$ \\
HE R.h & $67.61 \pm 0.01^{\mathrm{a}}$ & $7.15 \pm 0.02^{\mathrm{b}}$ \\
ER.h & $50.83 \pm 0.05^{\mathrm{b}}$ & $5.64 \pm 0.00^{\mathrm{b}}$ \\
\hline
\end{tabular}

Values with different letters are significantly different at $P<0.05$; Eq $C A T$ : catechin equivalent; Eq $G A E$ : gallic acid equivalent. AR.h: Aqueous extract of Raphia hookeri; HER.h: hydro-ethanolic extract of Raphia hookeri: ER.h: ethanol extract of Raphia hookeri; VIT C: vitamin C, w: weight. 
of extract and the highest flavonoïd content was also observed in aqueous extract (13.32 mg Eq CAT/g of extract).

\subsection{Antioxidants Capacity in Vitro of Raphia hookeri Mesocarp Extracts}

\subsubsection{DPPH Scavenging (2,2-Diphenyl-1-Picrylhydrazyl) of Raphia hookeri Mesocarp Extracts}

The DPPH radical scavenging of different extracts differs with different concentration and it is between $70 \%$ and $90 \%$. At the lower $(12.5 \mu \mathrm{g} / \mathrm{ml})$ concentration, there was no significant between different extracts. At the high concentration $(200 \mu \mathrm{g} / \mathrm{ml})$ the DPPH scavenging of different extract of $R h$ mesocarp are the same to those of vitamin $\mathrm{C}$ at the same concentration. The results obtained in this study globally show that all extracts (aqueous, ethanolic and hydroethanolic) of $R h$ are highly active against the DPPH radical (Figure 1).

\subsubsection{Values of the Efficient Concentration $50\left(\mathrm{EC}_{50}\right)$ of Raphia hookeri Mesocarp Extracts}

The efficient concentration 50 of different extracts of Raphia hookeri mesocarp are lowers and are no significant different between different extract (12.65 and $14.32 \mu \mathrm{g} / \mathrm{ml})$. Aqueous extract present the best EC50 (12.65 $\mu \mathrm{g} / \mathrm{ml})$. However the $\mathrm{EC}_{50}$ of different extracts significant $(P<0.05)$ differ to those of vitamin $\mathrm{C}$ (Table 2).

\subsubsection{Ferric Reducing Antioxidant Power (FRAP) of Raphia hookeri Mesocarp Extracts}

The reducing power of different extracts of $R h$ was greater and not significantly different at theses concentrations $12.5,100$ and $200 \mu \mathrm{g} / \mathrm{ml}$. In the concentration of 25 and $50 \mu \mathrm{g} / \mathrm{ml}$ aqueous and hydroethanolic extracts were significantly $(P<$ $0.05)$ different from that of ethanolic extracts of $R h$. No significant difference

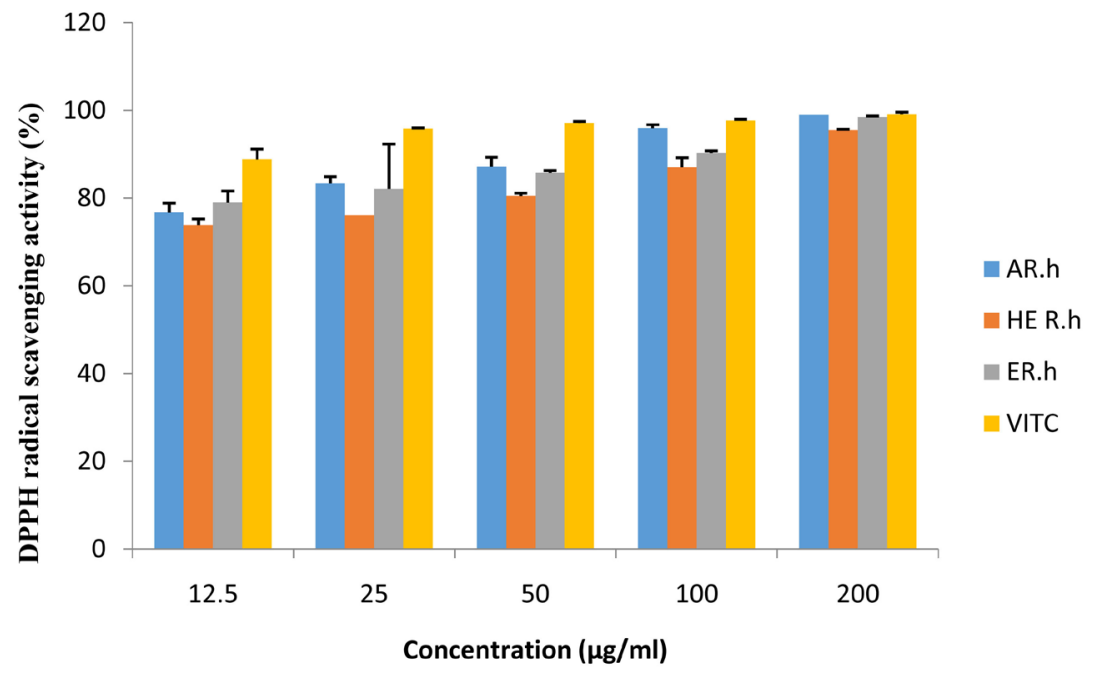

Figure 1. DPPH Radical Scavenging Activity of Raphia hookeri mesocarp extracts. AR.h: Aqueous extract of Raphia hookeri; HER.h: hydro-ethanolic extract of Raphia hookeri: ER.h: ethanol extract of Raphia hookeri, VIT C: vitamin C. 
Table 2. Value of the efficient concentration $50\left(\mathrm{EC}_{50}\right)$ of different extract and vitamin $\mathrm{C}$.

\begin{tabular}{cc}
\hline Extract & $\mathrm{EC}_{50}(\mu \mathrm{g} / \mathrm{ml})$ \\
\hline AR.h & $12.65 \pm 0.21^{\mathrm{b}}$ \\
HE R.h & $14.32 \pm 0.08^{\mathrm{b}}$ \\
ER.h & $13.71 \pm 0.08^{\mathrm{b}}$ \\
VITC & $4.78 \pm 0.00^{\mathrm{a}}$ \\
\hline
\end{tabular}

Values with different letters are significantly different at $P<0.05$.

between the power of reducing ferric iron to ferrous ion in the higher concentrations (100 and $200 \mu \mathrm{g} / \mathrm{ml}$ ) were observed (Figure 2).

\subsubsection{Hydroxyl Radical Scavenging Activity (HRSA) of Raphia hookeri Mesocarp Extracts}

Figure 3 present the hydroxyl radical scavenging activity of different extracts. At the lowers concentrations ( 12.5 and $25 \mu \mathrm{g} / \mathrm{ml}$ ), the hydroxyl radical scavenging activity of different extracts is very low and were no significant different to those of BHT. Nevertheless, in the high concentration $(200 \mu \mathrm{g} / \mathrm{ml})$, aqueous extract presented a significantly higher $(P<0.05)$ hydroxyl radical scavenging activity compared to ethanolic and hydroethanolic extracts of $R h$ (Figure 3 ).

\subsection{Protective Effect of Aqueous Extract and Different Formulation of $\boldsymbol{R h}$ Mesocarp against Aluminum Chloride-Induced Neurotoxity in Albino Rats}

\subsubsection{Effect of Aqueous Extract and Different Formulation of $R h$ Mesocarp on the Food Acquisition Speed}

Figure 4 shows the effect of aqueous extract and different formulation of $R h$ mesocarp on the food acquisition speed. Neurotoxicity induction leads to a significant decreased of food acquisition speed. Overall, administration of aqueous extract and different formulations of $R h(5 \%$ and $10 \%)$ significantly increased ( $P$ $<0.05)$ food acquisition speed in rats compared to the positive control the best values were obtained in groups ARh400 and Rh10\% (Figure 4).

\subsubsection{Effect of Aqueous Extract and Different Formulation of $R h$ Mesocarp on the Time Used to Find Platform}

Figure 5 shows the effect of aqueous extract and different formulations of $R h$ mesocarp on the time used to find platform. Stress induction led to a significant increase on the time used to find platforms. Overall, administration of aqueous extract, different formulations of $R h$ and vitamin $C$ significantly reduced $(P<$ $0.05)$ the time used to find platform compared to the positive control. The best value is obtained in group $\mathrm{ARh} 200$.

\subsection{Effect of $\boldsymbol{R h}$ on Some Biochemical Parameters}

\subsubsection{Effect of Aqueous Extract and Different Formulations of $R h$ Mesocarp on Glutathione Levels in Plasma and Tissue}

Table 3 shows the effect of aqueous extracts and different formulation of $R h$ 


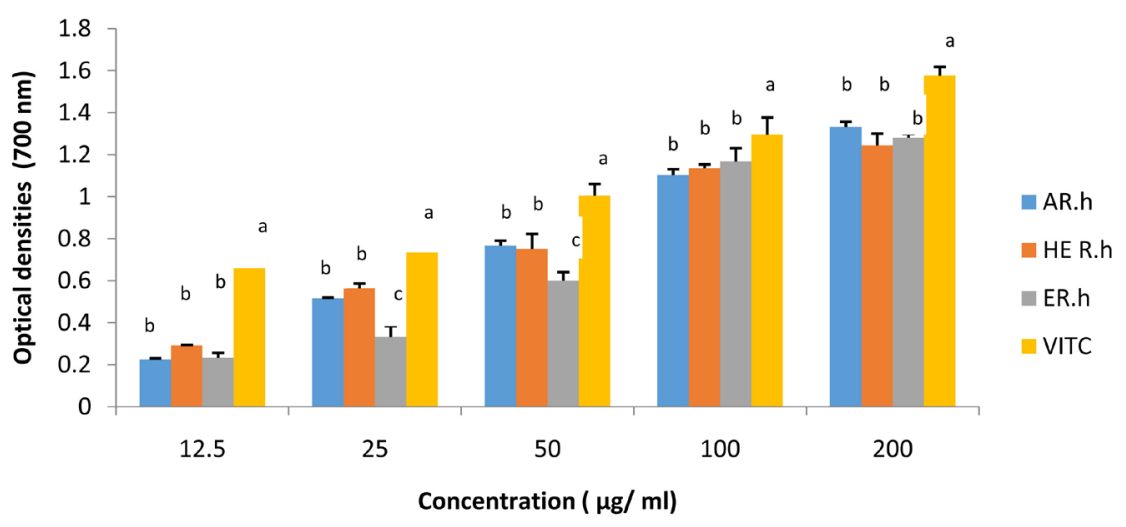

Figure 2. Ferric Reducing Antioxidant Power of Raphia hookeri mesocarp extracts. AR.h: Aqueous extract of Raphia hookeri; HER.h: hydro-ethanolic extract of Raphia hookeri: ER.h: ethanol extract of Raphia hookeri, VIT C: vitamin C.

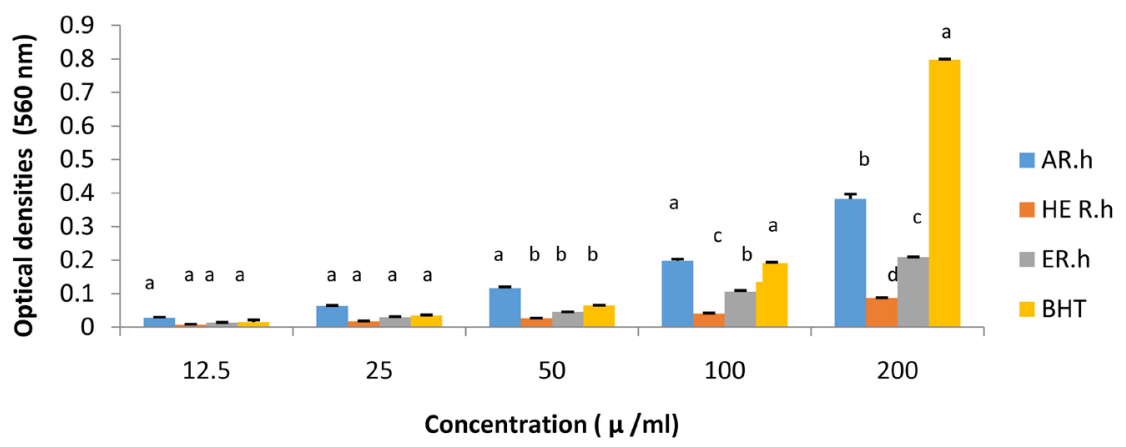

Figure 3. Hydroxyl Radical Scavenging Activity of Raphia hookeri mesocarp extracts. AR.h: Aqueous extract of Raphia hookeri; HER.h: hydro-ethanolic extract of Raphia hookeri: ER.h: ethanol extract of Raphia hookeri; BHT: butylhydroxytoluène.

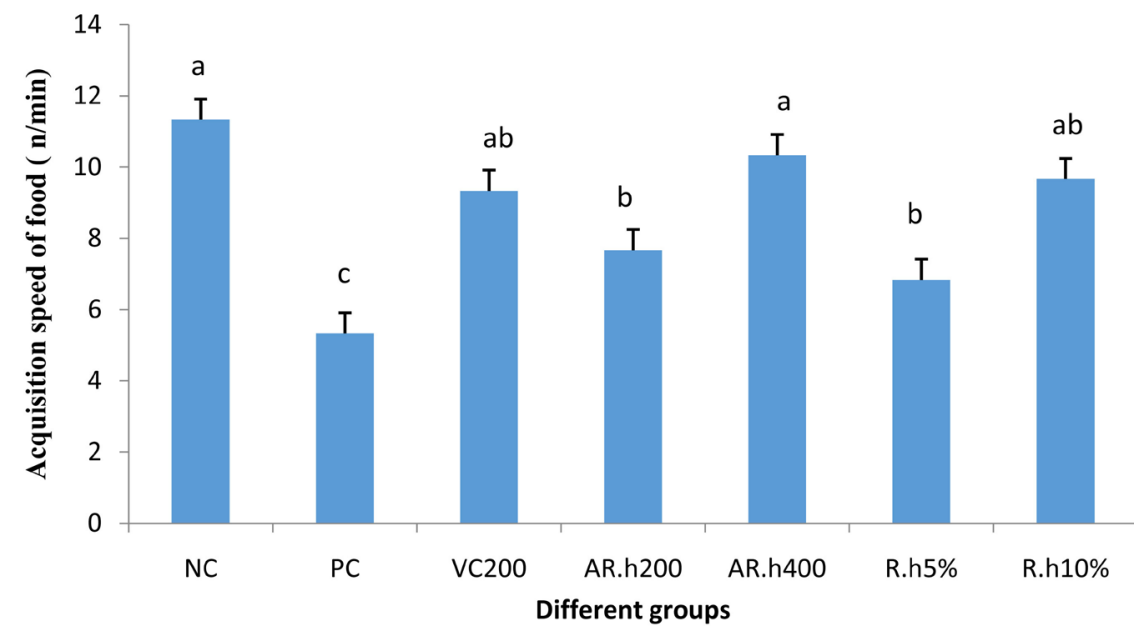

Figure 4. Effect of aqueous extract and different formulation of $R h$ mesocarp in the acquisition speed of food. NC: negative control received water; PC: induced rats (positive control rats) received water; AR.h 200: induced rats received $200 \mathrm{mg} / \mathrm{kg}$ bw aqueous extract of $R h$ mesocarp; AR.h 400: induced rats received $400 \mathrm{mg} / \mathrm{kg}$ bw aqueous extract of $R h$ mesocarp; R.h 5\%: induced rats received formulation food with 5\% of $R h$ mesocarp powder; R.h $10 \%$ : induced rats received formulation food with $10 \%$ of $R h$ mesocarp powder; VC 200: induced rats received $200 \mathrm{mg} / \mathrm{kg}$ bw of vitamin C. 


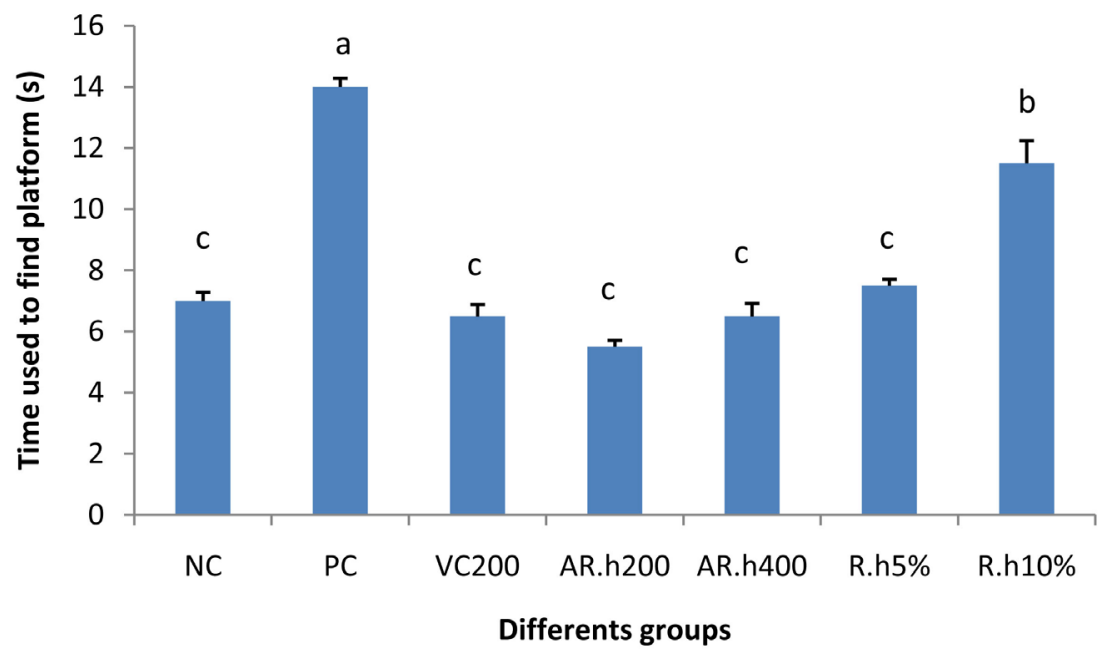

Figure 5. Effect of aqueous extract and different formulation of $R h$ mesocarp on the time used to find platform. NC: negative control received water; PC: induced rats (positive control rats) received water; AR.h 200: induced rats received $200 \mathrm{mg} / \mathrm{kg}$ bw aqueous extract of $R h$ mesocarp; AR.h 400: induced rats received $400 \mathrm{mg} / \mathrm{kg}$ bw aqueous extract of $R h$ mesocarp; $\mathrm{Rh} 5 \%$ : induced rats received formulation food with $5 \%$ of $R h$ mesocarp powder; $\mathrm{Rh} 10 \%$ : induced rats received formulation food with $10 \%$ of $R h$ mesocarp powder; VC200: induced rats received $200 \mathrm{mg} / \mathrm{kg}$ bw of vitamin C.

Table 3. Effect of aqueous extracts and different formulation of $R h$ mesocarp on the plasma, liver and brain reduced glutathione levels in rats.

\begin{tabular}{cccc}
\hline Groups & Plasma $(\mu \mathrm{mole} / \mathrm{ml})$ & Liver $(\mu \mathrm{mole} / \mathrm{g})$ & Brain $(\mu \mathrm{mole} / \mathrm{g})$ \\
\hline NC & $60.56 \pm 2.45^{\mathrm{c}}$ & $1063.97 \pm 37.32^{\mathrm{a}}$ & $663.99 \pm 59^{\mathrm{c}}$ \\
PC & $45.28 \pm 5.47^{\mathrm{d}}$ & $983.71 \pm 2.77^{\mathrm{b}}$ & $476.26 \pm 10.4^{\mathrm{e}}$ \\
VC 200 & $94.42 \pm 2.335^{\mathrm{a}}$ & $1061.63 \pm 2.03^{\mathrm{a}}$ & $683.65 \pm 84.41^{\mathrm{c}}$ \\
AR.h200 & $79.52 \pm 8.32^{\mathrm{b}}$ & $1064.82 \pm 3.62^{\mathrm{a}}$ & $773.4 \pm 24.3^{\mathrm{ab}}$ \\
AR.h400 & $90.71 \pm 2.385^{\mathrm{a}}$ & $1056.37 \pm 14.0^{\mathrm{a}}$ & $865.21 \pm 27.98^{\mathrm{a}}$ \\
R.h5\% & $83.365 \pm 5.505^{\mathrm{b}}$ & $1066.66 \pm 1.18^{\mathrm{a}}$ & $566.03 \pm 0.42^{\mathrm{d}}$ \\
R.h10\% & $78.15 \pm 7.34^{\mathrm{b}}$ & $1084.43 \pm 10.7^{\mathrm{a}}$ & $627.03 \pm 42.3^{\mathrm{c}}$ \\
\hline
\end{tabular}

The values of this table represent the means \pm standard deviation of 6 repetitions and the value which have different letters are significantly different at $P<0.05$; NC: negative controls and received water; PC: induced rats (positive control rats) received water; A.Rh 200: induced rats received $200 \mathrm{mg} / \mathrm{kg}$ bw aqueous extract of $R h$ mesocarp; A.Rh 400: induced rats received $400 \mathrm{mg} / \mathrm{kg}$ bw aqueous extract of $R h$ mesocarp; $\mathbf{R h}$ $5 \%$ : induced rats received formulation food with $5 \%$ of $R h$ mesocarp powder; $\mathrm{Rh} 10 \%$ : induced rats received formulation food with $10 \%$ of $R h$ mesocarp powder; VC200: induced rats received $200 \mathrm{mg} / \mathrm{kg}$ bw of vitamin C.

mesocarp on the plasma, liver and brain reduced glutathione levels in rats. Stress induction resulted in a significant decrease in the plasma, liver, and brain reduced glutathione levels in rats. However, administration of aqueous extract, different formulation of $R h$ mesocarp and vitamin $\mathrm{C}$ significantly increased $(P<$ 0.05 ) the levels of reduced glutathione in the plasma, liver and brain of the rats. $\mathrm{ARh} 400$ present the best value in plasma, liver and brain while the formulate groups presented the best value in liver. 


\subsubsection{Effect of Aqueous Extract and Different Formulations of $\boldsymbol{R h}$ Mesocarp on the Plasma and Tissue Malondialdehyde (MDA)}

Table 4 below shows the effects of stress induction and administration of aqueous extracts and different formulations of $R h$ on the level of the plasma, liver and brain malondialdehyde in rats. Stress induction resulted in a significant increase $(P<0.05)$ of the levels of malondialdehyde in the plasma, liver, and brain rats. Overall, administration of aqueous extract, different formulations of $R h$ and vitamin $C$ significantly decreased $(P<0.05)$ the levels of this malondialdehyde in the plasma, liver and brain. The best reduction is observed with the group AR.h400 in the plasma and in the group R.h5\% in the plasma, liver and brain.

\subsubsection{Effect of Aqueous Extract and Different Formulations of $R \boldsymbol{h}$ Mesocarp on the Plasma and Tissue Proteins}

Administration of aqueous extract, different formulations of $R h$ and vitamin $\mathrm{C}$ significantly increased $(P<0.05)$ the protein levels in plasma and homogenates of animals except in the liver of the group R.h5\% compared to positive control group (PC). The highest levels of protein were observed in the plasma, liver of the group AR.h200 and in the brain of the group AR.h400 (Table 5).

\subsubsection{Effects of Aqueous Extract and Different Formulations of $R \boldsymbol{h}$ Me- socarp on the Catalase Activity in the Plasma, Liver and Brain}

Stress induction resulted in a significant decrease $(P<0.05)$ activity of plasma, liver and brain catalase activity. Aqueous extract, different formulation of $R h$ and vitamin $\mathrm{C}$ administration significantly increase $(P<0.05)$ the activity of catalase in plasma, liver and brain in all the groups except in the liver and brain of group AR.h400. The best catalase activity is observed with the group AR.h400 in the plasma, groupAR.h200 in the liver and group R.h5\% in the brain (Table 6).

Table 4. Effects of stress induction and administration of aqueous extracts and different formulations of $R h$ on the level of the malondialdehyde in the plasma, liver and brain.

\begin{tabular}{|c|c|c|c|}
\hline Groups & Plasma $(\mu \mathrm{mole} / \mathrm{ml})$ & Liver $(\mu \mathrm{mole} / \mathrm{g})$ & Brain $(\mu \mathrm{mole} / \mathrm{g})$ \\
\hline $\mathrm{NC}$ & $0.66 \pm 0.03^{b}$ & $38.29 \pm 6.21^{b c}$ & $38.34 \pm 1.71^{b}$ \\
\hline PC & $1.13 \pm 0.1^{\mathrm{a}}$ & $63.79 \pm 2.16^{\mathrm{a}}$ & $59.48 \pm 0.28^{\mathrm{a}}$ \\
\hline VC 200 & $0.63 \pm 0.06^{\mathrm{b}}$ & $35.06 \pm 0.07^{\mathfrak{c}}$ & $24.14 \pm 0.08^{\mathrm{d}}$ \\
\hline AR.h200 & $0.65 \pm 0.01^{b}$ & $48.59 \pm 0.57^{b}$ & $31.32 \pm 2.36^{b c}$ \\
\hline AR.h 400 & $0.47 \pm 0.04^{\mathrm{c}}$ & $45.77 \pm 0.30^{\mathrm{b}}$ & $30.55 \pm 3.83^{c}$ \\
\hline R.h5\% & $0.44 \pm 0.02^{\mathrm{c}}$ & $38.72 \pm 0.57^{\mathrm{bc}}$ & $22.25 \pm 0.63^{d}$ \\
\hline R.h10\% & $0.65 \pm 0.01^{\mathrm{bc}}$ & $48.75 \pm 10.1^{\mathrm{b}}$ & $33.075 \pm 2.51^{\mathrm{b}}$ \\
\hline
\end{tabular}

The values of this table represent the means \pm standard deviation of 6 repetitions and the value which have different letters are significantly different at $P<0.05$; NC: negative controls and received water; PC: induced rats (positive control rats) received water; A.Rh 200: induced rats received $200 \mathrm{mg} / \mathrm{kg}$ bw aqueous extract of $R h$ mesocarp; A.Rh 400: induced rats received $400 \mathrm{mg} / \mathrm{kg}$ bw aqueous extract of $R h$ mesocarp; Rh 5\%: induced rats received formulation food with 5\% of $R h$ mesocarp powder; $\mathbf{R h} 10 \%$ : induced rats received formulation food with $10 \%$ of $R h$ mesocarp powder; VC200: induced rats received $200 \mathrm{mg} / \mathrm{kg}$ bw of vitamin C. 
Table 5. Proteins levels in the plasma, liver and brain of rats.

\begin{tabular}{cccc}
\hline Groups & Plasma $(\mu \mathrm{mole} / \mathrm{ml})$ & Liver $(\mu \mathrm{mole} / \mathrm{g})$ & Brain $(\mu \mathrm{mole} / \mathrm{g})$ \\
\hline NC & $174.33 \pm 6.46^{\mathrm{bc}}$ & $319.435 \pm 0.26^{\mathrm{d}}$ & $40.43 \pm 12^{\mathrm{b}}$ \\
PC & $137.61 \pm 7.69^{\mathrm{e}}$ & $143.98 \pm 2.96^{\mathrm{e}}$ & $13.91 \pm 0.28^{\mathrm{e}}$ \\
VC 200 & $183.72 \pm 5.66^{\mathrm{b}}$ & $643.76 \pm 9.46^{\mathrm{a}}$ & $24.205 \pm 0.28^{\mathrm{d}}$ \\
AR.h200 & $202.57 \pm 11.82^{\mathrm{a}}$ & $524.07 \pm 0.32^{\mathrm{b}}$ & $31.32 \pm 2.36^{\mathrm{c}}$ \\
AR.h400 & $165.31 \pm 3.33^{\mathrm{d}}$ & $371.57 \pm 34.17^{\mathrm{c}}$ & $29.28 \pm 8.03^{\mathrm{c}}$ \\
R.h5\% & $187.03 \pm 6.33^{\mathrm{b}}$ & $173.41 \pm 0.86^{\mathrm{e}}$ & $31.25 \pm 1.03^{\mathrm{c}}$ \\
R.h10\% & $197.68 \pm 16.27^{\mathrm{a}}$ & $306.93 \pm 3.46^{\mathrm{d}}$ & $51.40 \pm 15.35^{\mathrm{a}}$ \\
\hline
\end{tabular}

The values of this table represent the means \pm standard deviation of 6 repetitions and the value which have different letters are significantly different at $P<0.05$; NC: negative controls and received water; PC: induced rats (positive control rats) received water; A.Rh 200: induced rats received $200 \mathrm{mg} / \mathrm{kg}$ bw aqueous extract of $R h$ mesocarp; A.Rh 400: induced rats received $400 \mathrm{mg} / \mathrm{kg}$ bw aqueous extract of $R h$ mesocarp; $\mathbf{R h}$ 5\%: induced rats received formulation food with $5 \%$ of $R h$ mesocarp powder; Rh $10 \%$ : induced rats received formulation food with $10 \%$ of $R h$ mesocarp powder; VC200: induced rats received $200 \mathrm{mg} / \mathrm{kg}$ bw of vitamin C.

Table 6. Effects of oxidative stress and different formulations on the activity of the plasma, liver, and brain catalase.

\begin{tabular}{cccc}
\hline Groups & Plasma $(\mathrm{nmol} / \mathrm{min} / \mathrm{ml})$ & Liver $(\mathrm{nmol} / \mathrm{min} / \mathrm{g})$ & Brain $(\mathrm{nmol} / \mathrm{min} / \mathrm{ml})$ \\
\hline NC & $2.67 \pm 0.18^{\mathrm{b}}$ & $0.78 \pm 0.09^{\mathrm{b}}$ & $1.66 \pm 0.05^{\mathrm{c}}$ \\
PC & $1.33 \pm 0.06^{\mathrm{c}}$ & $0.64 \pm 0.05^{\mathrm{c}}$ & $1.39 \pm 0.005^{\mathrm{d}}$ \\
VC 200 & $3.05 \pm 0.08^{\mathrm{a}}$ & $0.90 \pm 0.06^{\mathrm{a}}$ & $2.28 \pm 0.01^{\mathrm{a}}$ \\
AR.h200 & $2.55 \pm 0.15^{\mathrm{b}}$ & $0.88 \pm 0.01^{\mathrm{b}}$ & $1.74 \pm 0.01^{\mathrm{bc}}$ \\
AR.h400 & $2.64 \pm 0.05^{\mathrm{b}}$ & $0.74 \pm 0.01^{\mathrm{bc}}$ & $1.68 \pm 0.07^{\mathrm{c}}$ \\
R.h5\% & $2.29 \pm 0.31^{\mathrm{b}}$ & $0.74 \pm 0.05^{\mathrm{bc}}$ & $1.83 \pm 0.06^{\mathrm{b}}$ \\
R.h10\% & $2.27 \pm 0.34^{\mathrm{b}}$ & $0.86 \pm 0.03^{\mathrm{b}}$ & $1.64 \pm 0.06^{\mathrm{b}}$ \\
\hline
\end{tabular}

The values of this table represent the means \pm standard deviation of 6 repetitions and the value which have different letters are significantly different at $P<0.05$; NC: negative controls and received water; PC: induced rats (positive control rats) received water; A.Rh 200: induced rats received $200 \mathrm{mg} / \mathrm{kg}$ bw aqueous extract of $R h$ mesocarp; A.Rh 400: induced rats received $400 \mathrm{mg} / \mathrm{kg}$ bw aqueous extract of $R h$ mesocarp; $\mathbf{R h}$ 5\%: induced rats received formulation food with $5 \%$ of $R h$ mesocarp powder; $\mathrm{Rh} 10 \%$ : induced rats received formulation food with $10 \%$ of $R h$ mesocarp powder; VC200: induced rats received $200 \mathrm{mg} / \mathrm{kg}$ bw of vitamin C.

\subsubsection{Effects of Aqueous Extract and Different Formulations of $R h$ Mesocarp on the Nitric Oxide (NO) in the Plasma, Liver and Brain}

Stress induction resulted in a significant increase $(P<0.05)$ activity in the plasma, liver and brain of nitric oxide. However, aqueous extract, different formulation of $R h$ and vitamin $C$ significantly decreased $(P<0.05)$ the levels of nitric oxide in the plasma and organs of these animals compared to the positive control. The best reduction of nitric oxide is observed with the group R.h $10 \%$ in the plasma, liver and with the group R.h5\% in brain (Table 7).

\subsubsection{Effect of Aqueous Extract and Different Formulations of Rh} Mesocarp on the Plasma and Tissue Super Oxide Dismutase (SOD)

Table 8 shows the effect of aqueous extracts and different formulation of $R h$ on 
Table 7. Effect of aqueous extracts and different formulation of $R h$ on the level of the plasma, liver and brain nitric oxide in rats.

\begin{tabular}{cccc}
\hline Groups & Plasma $(\mu \mathrm{mol} / \mathrm{ml})$ & Liver $(\mu \mathrm{mol} / \mathrm{g})$ & Brain $(\mu \mathrm{mol} / \mathrm{g})$ \\
\hline NC & $1992.75 \pm 112.9^{\mathrm{e}}$ & $491893.5 \pm 778^{\mathrm{d}}$ & $304.15 \pm 50.8^{\mathrm{bc}}$ \\
PC & $8751.35 \pm 76.7^{\mathrm{a}}$ & $5829026 \pm 799.5^{\mathrm{a}}$ & $583.725 \pm 46.08^{\mathrm{a}}$ \\
VC 200 & $4956.25 \pm 51.55^{\mathrm{b}}$ & $2806866.05 \pm 4703.5^{\mathrm{b}}$ & $372.215 \pm 43.5^{\mathrm{b}}$ \\
AR.h200 & $5290 \pm 160^{\mathrm{c}}$ & $1249728.5 \pm 3839.5^{\mathrm{d}}$ & $283.74 \pm 16.45^{\mathrm{bc}}$ \\
AR.h400 & $4840.1 \pm 478.3^{\mathrm{b}}$ & $1724481 \pm 3271^{\mathrm{c}}$ & $293.05 \pm 52.25^{\mathrm{bc}}$ \\
R.h5\% & $4912 \pm 379.5^{\mathrm{b}}$ & $844519.5 \pm 5224^{\mathrm{e}}$ & $190.585 \pm 24.31^{\mathrm{d}}$ \\
R.h10\% & $2805.3 \pm 67.1^{\mathrm{d}}$ & $820630 \pm 2846.5^{\mathrm{e}}$ & $276.65 \pm 80^{\mathrm{bc}}$ \\
\hline
\end{tabular}

The values of this table represent the means \pm standard deviation of 6 repetitions and the value which have different letters are significantly different at $P<0.05$; NC: negative controls and received water; PC: induced rats (positive control rats) received water; A.Rh 200: induced rats received $200 \mathrm{mg} / \mathrm{kg}$ bw aqueous extract of $R h$ mesocarp; A.Rh 400: induced rats received $400 \mathrm{mg} / \mathrm{kg}$ bw aqueous extract of $R h$ mesocarp; $\mathbf{R h}$ $5 \%$ : induced rats received formulation food with $5 \%$ of $R h$ mesocarp powder; $\mathbf{R h} 10 \%$ : induced rats received formulation food with $10 \%$ of $R h$ mesocarp powder; VC 200 : induced rats received $200 \mathrm{mg} / \mathrm{kg}$ bw of vitamin C.

Table 8. Effect of aqueous extracts and different formulation of $R h$ on the plasma, liver and brain super oxide dismutase levels in rat.

\begin{tabular}{cccc}
\hline Groups & Plasma $(\mu$ mole $/ \mathrm{min} / \mu \mathrm{l})$ & Liver $(\mu \mathrm{mole} / \mathrm{min} / \mathrm{mg})$ & Brain $(\mu \mathrm{mole} / \mathrm{min} / \mathrm{mg})$ \\
\hline NC & $3697.33 \pm 7.77^{\mathrm{a}}$ & $372.13 \pm 6.87^{\mathrm{a}}$ & $368.2 \pm 2.945^{\mathrm{a}}$ \\
PC & $2492.43 \pm 139.74^{\mathrm{b}}$ & $241.65 \pm 44.81^{\mathrm{b}}$ & $219 \pm 53^{\mathrm{b}}$ \\
VC 200 & $3721.35 \pm 33.65^{\mathrm{a}}$ & $370.4 \pm 6.93^{\mathrm{a}}$ & $367.73 \pm 4.41^{\mathrm{a}}$ \\
AR.h200 & $3713.31 \pm 15.11^{\mathrm{a}}$ & $372.73 \pm 6.39^{\mathrm{a}}$ & $368.73 \pm 7.51^{\mathrm{a}}$ \\
AR.h400 & $3708.7 \pm 37.1^{\mathrm{a}}$ & $370.6 \pm 6.7^{\mathrm{a}}$ & $369.73 \pm 9.14^{\mathrm{a}}$ \\
R.h5\% & $3741 \pm 50.92^{\mathrm{a}}$ & $370.46 \pm 6.56^{\mathrm{a}}$ & $376.75 \pm 15.38^{\mathrm{a}}$ \\
R.h10\% & $3680.8 \pm 28.76^{\mathrm{a}}$ & $371.03 \pm 8.06^{\mathrm{a}}$ & $369.4 \pm 8.84^{\mathrm{a}}$ \\
\hline
\end{tabular}

The values of this table represent the means \pm standard deviation of 6 repetitions and the value which have different letters are significantly different at $P<0.05$; NC: negative controls and received water; PC: induced rats (positive control rats) received water; A.Rh 200: induced rats received $200 \mathrm{mg} / \mathrm{kg}$ bw aqueous extract of $R h$ mesocarp; A.Rh 400: induced rats received $400 \mathrm{mg} / \mathrm{kg}$ bw aqueous extract of $R h$ mesocarp; $\mathbf{R h} 5 \%$ : induced rats received formulation food with $5 \%$ of $R h$ mesocarp powder; $\mathrm{Rh} 10 \%$ : induced rats received formulation food with $10 \%$ of $R h$ mesocarp powder; VIT C: induced rats received $200 \mathrm{mg} / \mathrm{kg}$ bw of vitamin C.

the plasma, liver and brain super oxide dismutase levels in rats. Administration of aqueous extract, different formulation of $R h$ and vitamin $C$ significantly increased $(P<0.05)$ the levels of super oxide dismutase in the plasma and organs compared to the positive control.

\subsubsection{Effect of Aqueous Extract and Different Formulations of $R \boldsymbol{h}$ Mesocarp on the Brain Acetylcholinesterase Activity}

Stress induction resulted in a significant increase of acetylcholinesterase activity of the animals. Overall, administration of aqueous extract, different formulation of $R h$ and vitamin $C$ significantly decreased $(P<0.05)$ the levels of acetylcholi- 
nesterase in the brain of these animals compared to that of the positive control. The best reduction of acetylcholinesterase activity is obtained with the high doses of extract and formulation (Rh10\% and ARh400 respectively) (Table 9).

\section{Discussion}

\subsection{Total Phenolic and Flavonoïd Content}

Phenolic compounds are the major secondary metabolites found in plants which are used for their defence. Antioxidant activity of plant extracts has been attributed to these molecules [9] [25]. The fact that $R h$ extracts are rich in phenolic compounds has been proved [25]. It was reported that the total phenolic content of aqueous extract of $R h$ was $4.1 \mathrm{~g} \cdot \mathrm{kg}^{-1}$ of powder. In the same line, the total phenolic content of $R h$ leaf was $39.73 \mathrm{mg} \mathrm{GAE} / \mathrm{g}$ [26]. The values obtained by Ogbuagu and Dada were significantly lower than those obtained in this study. This can be attributed to genotypic and environmental differences (climate, temperature, location) between these plants, the choice of the part tested, the harvesting period, the extraction and characterization methods [27] [28].

Flavonoïds are the most represented family of phenolic compounds. They have a good antioxidant activity through several mechanisms of action [29]. This has been related to their complex structure compared to that of phenolic acids. The presence of flavonoïds in $R h$ extract has already been reported [30]. Ogbuagu demonstrated that the flavonoï content of aqueous extract of $R h$ mesocarp was 4 $\mathrm{g} \cdot \mathrm{kg}^{-1}$ of powder. On the other hand the flavonoïd content of $R h$ leaf was 21.88 mg QAE/g [26]. The flavonoïd content obtained in this study was significantly lower than those reported by these authors. This result can be justified by the environmental conditions, the part of the plant used the nature of the extraction solvent and the maturity step of the plant can explain these variations [27] [28].

Table 9. Effect of aqueous extracts and different formulation of $R h$ on the level of brain acetylcholinesterase activity in rats.

\begin{tabular}{cc}
\hline Groups & Brain (nmol/min/mg prot) \\
\hline NC & $0.03 \pm 0.00^{\mathrm{f}}$ \\
PC & $0.34 \pm 0.069^{\mathrm{a}}$ \\
VC 200 & $0.09 \pm 0.015^{\mathrm{c}}$ \\
AR.h200 & $0.26 \pm 0.05^{\mathrm{b}}$ \\
AR.h400 & $0.054 \pm 0.02^{\mathrm{d}}$ \\
R.h5\% & $0.054 \pm 0.005^{\mathrm{d}}$ \\
R.h10\% & $0.04 \pm 0.005^{\mathrm{e}}$ \\
\hline
\end{tabular}

The values of this table represent the means \pm standard deviation of 6 repetitions and the value which have different letters are significantly different at $P<0.05$; NC: negative controls and received water; PC: induced rats (positive control rats) received water; A.Rh 200: induced rats received $200 \mathrm{mg} / \mathrm{kg}$ bw aqueous extract of $R h$ mesocarp; A.Rh 400: induced rats received $400 \mathrm{mg} / \mathrm{kg}$ bw aqueous extract of $R h$ mesocarp; $\mathbf{R h} \mathbf{5 \%}$ : induced rats received formulation food with $5 \%$ of $R h$ mesocarp powder; $\mathrm{Rh} 10 \%$ : induced rats received formulation food with $10 \%$ of $R h$ mesocarp powder; VIT C: induced rats received $200 \mathrm{mg} / \mathrm{kg}$ bw of vitamin C. 


\subsection{Antioxidant Activity}

\subsubsection{DPPH Radical Scavenging Assay}

Generally, the plant extracts which have higher phenolic and flavonoïd contents have also presented the best antioxidant activities. The $\mathrm{CE}_{50}$ values obtained for aqueous, hydroethanolic and ethanolic solvents of Raphia hookeri mesocarp in the DPPH assay were $12.65,14.32$ and $13.71 \mu \mathrm{g} / \mathrm{ml}$ respectively. These values were lower than those of Oluyori et al. who showed the values of $0.0523 \mathrm{mg} / \mathrm{ml}$ and $0.1126 \mathrm{mg} / \mathrm{ml}$ respectively for the epicarp and the leaf compare to the $\mathrm{CE}_{50}$ value of our mesocarp. It can be due to the difference between the parts of the plant used. These results corroborated with previous studies [9] which reported that plants with high phenolic content generally exhibit high DPPH Radical Scavenging Activity.

\subsubsection{Ferric Reducing Antioxidant Power (FRAP)}

The reducing antioxidant power of Raphia hookeri was due to the presence of hydroxyl group in phenolic compounds such as flavonoïds which can reduce ferric ions in ferrous ions. The presence of high ferrous was due to the high power of the extract to reduce ferric ions and thus the antioxidant activity [31].

\subsubsection{Hydroxyl Radical Scavenging Activity (HRSA)}

The highest activity was recorded with the aqueous extract of $R h$. The active molecule extracted from the mesocarp of these plants may have several mechanisms of action. This can be explained by the fact that the antioxidant which has the ability to scavenge the hydroxyl radical was most extracted by distilled water [31]. Overall, the reducing power was correlated to the polyphenol contents and DPPH scavenging activity.

\subsection{Effect of Aqueous Extract and Different Formulation of $\boldsymbol{R} \boldsymbol{h}$ Mesocarp on the Acquisition Speed of Food and on the Time Used to Find Platform}

The induction of stress leads to a significant reduction of the acquisition speed of food and the increasing of time used to find platform. These can be explained by the loss of memory capacity due to aluminum chloride which can induce oxidative damage through multiple mechanisms. It can bind to negatively charged brain phospholipids, which contain polyunsaturated fatty acids and are easily attacked by reactive oxygen species. It can also interfere with the homeostasis of metals and disturbed the permeability of the membrane cells (ROS) [32]. Treatment with aqueous extract and formulation shows the best results in the high doses (ARh400 and Rh10\% respectively). This result can be explained by the presence of some micronutrients in food. In the same line, flavonoïds have been reported to have substantial neuroprotective activity [4]. These effects have been attributed to their general free radical trapping capacity, antioxidant activity on neurons, but they also intervene in multiple biological processes, such as iron chelation, activation of survival genes, cell signaling pathways and regulation of mitochondrial function [3]. 


\subsection{Effect of $R h$ on Some Biochemical Parameters}

\subsubsection{Effect of Aqueous Extract and Different Formulations of $R \boldsymbol{h}$ Mesocarp on Glutathione Levels in Plasma and Tissue (Liver and Brain)}

Total glutathione content is a major cellular antioxidant that preserves the oxido-reductive balance in the cell. Administration of aqueous extract, different formulations of $R h$ mesocarp (5\% and 10\%) and vitamin C significantly increased $(P<0.05)$ the levels of reduced glutathione in the plasma, liver and brain of the rats. These results are similar to those reported with previous studies [33] which showed that metals such as cadmium and mercury result in oxidative stress by reduction in renal and brain intracellular glutathione. Indeed, polyphenols, namely flavonoïds, present in extracts and powder of $R h$ mesocarp modulate the expression of the enzyme gamma glutamyl synthetase in the cellular antioxidant defense. This enzyme is responsible for the rate of synthesis of glutathione. These studies are consistent with those of who showed that flavonoïds increase the expression of gamma-glutamyl synthetase in vitro and in vivo in mice transgenic strain.

\subsubsection{Effect of Aqueous Extract and Different Formulations of $\boldsymbol{R} \boldsymbol{h}$ Mesocarp on the Plasma and Tissue Malondialdehyde (MDA)}

The increase of malondialdehyde level in the positive control group is due to the fact that aluminum can bind to negatively charged brain phospholipids, which contain polyunsaturated fatty acids and are easily attacked by reactive oxygen species (ROS) [33] Furthermore, this element stimulates iron-initiated lipid peroxidation in the redox reaction, which causes ROS production and $\mathrm{Fe}^{3+}$ formations [33]. Reactive oxygen species may also cause cellular damage, by oxidizing amino acid residues on proteins, forming protein carbonyls suggesting for $\mathrm{Al}$ to have catalytic activity to produce free radicals. Furthermore, the main mechanism of $\mathrm{Al}$ toxicity involves the disruption of the homeostasis of metals, such as magnesium $(\mathrm{Mg})$, calcium $(\mathrm{Ca})$, and iron $(\mathrm{Fe})$.

\subsubsection{Effect of Aqueous Extract and Different Formulations of $\boldsymbol{R} \boldsymbol{h}$ Mesocarp on Proteins in the Plasma and Tissue}

The decrease in the plasma, liver, and brain protein levels in the positive control group compared to those of the treated groups can be explained by the fact that aluminum can bind to different metal binding proteins such as $\mathrm{Ca}, \mathrm{Fe}, \mathrm{Cu}$ and $\mathrm{Zn}$ that accordingly influence homeostasis of other metals. Aluminum may exert its neurotoxicity via free radical production and peroxidation damage to lipids and proteins. Similarly, it could also be due to reactive oxygen species formed such as hydroxyl radicals responsible for the oxidation of the side chains of some amino acids resulting in proteins hydrolysis. These changes could affect their functions, antigenicity, and proteolytic degradation in the proteasome. These results are corroborated with previous studies [34] who showed a decrease in protein levels after intraperitoneal injection of aluminum in rats at a dose of 40 $\mathrm{mg} / \mathrm{kg}$ bw. 


\subsubsection{Effect of Aqueous Extract and Different Formulations of $\boldsymbol{R} \boldsymbol{h}$ Mesocarp on the Activity of the Plasma, Liver and Brain Catalase}

The observed decrease of the catalase activity during $\mathrm{AlCl}_{3}$-induction is in accordance with that previously reported [35]. Catalase constitutes a supportive team of enzyme. In the occurrence of inadequate catalase level to degrade $\mathrm{H}_{2} \mathrm{O}_{2}$, more $\mathrm{H}_{2} \mathrm{O}_{2}$ could be converted to toxic hydroxyl radicals that may contribute to oxidative stress. In the present study, the decline in the activities of catalase in plasma and homogenates of $\mathrm{AlCl}_{3}$ rat group might be due to their inactivation caused by excess reactive oxygen species production.

\subsubsection{Effect of Aqueous Extract and Different Formulations of $\boldsymbol{R} \boldsymbol{h}$ Mesocarp on Nitric Oxide (NO) in the Plasma, Liver and Brain}

The data revealed a significant increase in nitric oxide content in $\mathrm{AlCl}_{3}$ treated group. This elevation in nitric oxide could be attributed to the ability of aluminum to generate reactive oxygen species and free radicals. One of the multiple pathways to increase free radicals mediated neurotoxicity is the formation of peroxynitrite by reaction of nitric oxide and superoxide radical [36].

\subsubsection{Effect of Aqueous Extract and Different Formulations of Rh} Mesocarp on the Plasma and Tissue Super Oxide Dismutase (SOD) Superoxide dismutase (SOD) belongs to the members of enzymatic antioxidative defense mechanisms against reactive oxygen species, and protects macromolecules, cells and cell membranes from peroxidative damage [37]. The decrease of SOD in positive group leads to peroxidative damage of brain tissues that may result to oxidative stress. Comparable findings were also obtained by Ahkam and El-Gendy who demonstrated that one month administration of $\mathrm{AlCl}_{3}$ at dose level of $53.5 \mathrm{mg}$ through drinking water significantly decreased the activities of SOD [38].

\subsubsection{Effect of Aqueous Extract and Different Formulations of $\boldsymbol{R} \boldsymbol{h}$ Mesocarp on the Brain Acetylcholinesterase Activity}

The data obtained reveled that $\mathrm{AlCl}_{3}$ induced significant increase in AchE activity in the brain of rats. This result was parallel to those recorded by previous authors [39] who observed a significant increase in AchE activity in rat treated with $\mathrm{AlCl}_{3}(50 \mathrm{mg} / \mathrm{kg})$ daily in drinking water for three months. Also, it was reported that AchE activity in different brain regions increased after 4 and 14 day from oral administration of $\mathrm{AlCl}_{3}$ at a dose of $320 \mathrm{mg} / \mathrm{kg}$ body weight [40]. This elevation in AchE activity may be attributed to the direct neurotoxic effect of metal or a disarrangement of the cell membrane caused by increased lipid peroxidation as reported by the previous study [41]. However, administration of different extract and formulations leads to a significant reduction of this acetylcholine activity. The best reductions were observed in groups ARh400 and Rh10\%. Our result corroborated the previous authors who reported that administration of polyphenol present in wild blueberry extract attenuated brain oxidative stress by decreased acetylcholinesterase activity in adult mice [41].

This study showed that during the 4 weeks of $R h$ supplemented diets, the re- 
ductions of the time use to find platform and the increase of the acquisition speed of food in the rat were due to the presence in this powder and extracts of some phytochemicals compounds. Many phytochemicals compounds have been shown to exert neuroprotective actions in animal and cell culture models of neurological disorders [39]. The vast majority of the studies on health focused on the fact that many of the active chemicals possess antioxidant activities. Neuroprotective effects of various phytochemicals are thus associated with reduced levels of oxidative stress which was observed in our study by the increase of protein levels, catalase activity, glutathione, super oxide dismutase concomitant to the reduce levels of malondialdehyde, nitric oxide and acetylcholine esterase activity. This antioxidant represented the keys of the detoxification in our bodies and can be stimulated by the presence in the extract and powder of $R h$ mesocarp of some phytochemicals compounds such as polyphenols, like flavonoïds rely on their ability to cross the blood-brain barrier and directly scavenge pathological concentrations of reactive oxygen and nitrogen species and chelate transition metal ions. Different polyphenolic compounds were shown to have scavenging activity and the ability to activate key antioxidant enzymes in the brain, thus breaking the vicious cycle of oxidative stress and tissue damage [39].

\section{Conclusion}

According to the present results, it could be concluded that Raphia hookeri mesocarp by enhancing antioxidant activities, cognitive functions (reduced the time used to find the platform and increase the acquisition spend of food), increases catalase, protein, glutathione, superoxide dismutase and decreases malondialdehyde, nitric oxide and acetylcholine esterase activity. Therefore $R h$ mesocarp would protect oxidative damage and preserve neurone functions.

\section{Acknowledgements}

The authors thank gratefully Professor Kuiate Jules Roger and Professor Zambou Ngoufack Francois of the Department of Biochemistry, University of Dschang.

\section{Conflicts of Interest}

The authors declare no conflicts of interest regarding the publication of this paper.

\section{References}

[1] Bassioni, G., Mohammed, F.S., Al Zubaidy, E. and Kobrsi, I. (2012) Risk Assessment of Using Aluminum Foil in Food Preparation. International Journal Electrochem Sciences, 7, 4498-4509.

[2] Butterfield, D. (2002) Amyloid Beta-Peptide (1-42)-Induced Oxidative Stress and Neurotoxicity: Implications for Neurodegeneration in Alzheimer's Disease Brain. A Review. Free Radical Research, 36, 1307-1313. https://doi.org/10.1080/1071576021000049890 
[3] Pieta, P. (2000) Flavonoïds as Antioxidants. Journal of Natural Products, 63, 1035-1042. https://doi.org/10.1021/np9904509

[4] Rahman, I. and Adcock, I. (2006) Oxidative Stress and Redox Regulation of Lung Inflammation in COPD. The European Respiratory Journal, 28, 219-242. https://doi.org/10.1183/09031936.06.00053805

[5] Ogbuagu, N. (2008) Vitamins, Phytochemicals and Toxic Elements in the Pulp and Seed of Raphia Palm Fruit (Raphia hookeri). Fruits, 63, 297-302. https://doi.org/10.1051/fruits:2008025

[6] Dore, S. (2005) Unique Properties of Polyphenol Stilbenes in the Brain: More than Direct Antioxidant Actions; Gene/Protein Regulatory Activity. Neurosignals, 14, 61-70. https://doi.org/10.1159/000085386

[7] Ohimain, E., Tuwon, P. and Ayibaebi, E. (2012) Traditional Fermentation and Distillation of Raffia Palm Sap for the Production of Bioethanol in Bayelsa State. Nigeria Journal of Technology Innovations in Renewable Energy, 1, 131-141. https://doi.org/10.6000/1929-6002.2012.01.02.8

[8] Ukwubile, A., Otalu, O. and Babalola, J. (2013) Evaluation of Ichthyotoxicity Activity of Raphiafarinifera, (Gaertn) Hyl. (Arecaceae) Fruits Extract. Standard Research Journal of Toxicology and Environmental Health Sciences, 1, 17-20.

[9] Womeni, H., Djikeng, F., Anjaneyulu, B., Karuna, M., Prasad, R. and Linder, M. (2016) Oxidative Stabilization of RBD Palm Olein under Forced Storage Conditions by Old Cameroonian Green Tea Leaves Methanolic Extract. NFS Journal, 3, 33-40. https://doi.org/10.1016/j.nfs.2016.03.002

[10] Gao, X., Ohlander, M., Jeppsson, N., Bjork, L. and Trajkovski, V. (2000) Changes in Antioxidant Effects and Their Relationship to Phytonutrients in Fruits of Sea Buckthorn (Hippophae rhamnoides L) during Maturation. Journal of Agricultural and Food Chemistry, 48, 1485-1490. https://doi.org/10.1021/jf991072g

[11] Quettier, D., Gressier, B., Vasseur, J., Dine, T., Brunet, C., Luyckx, M., Cayin, C., Bailleul, F. and Trotin, F. (2000) Phenolic Compounds and Antioxidant Activities of Buckwheat (Fagopyrum esculentum Moench) Hulls and Flour. Journal of Ethnopharmacology, 72, 35-42. https://doi.org/10.1016/S0378-8741(00)00196-3

[12] Braca, A., Sortino, C. and Politi, M. (2002) Antioxidant Activity of Flavonoïds from Licanialicaniae flora. Journal of Ethnopharmacology, 79, 379-381. https://doi.org/10.1016/S0378-8741(01)00413-5

[13] Oyaizu, M. (1986) Studies on Products of Browning Reactions: Antioxidative Activities of Products of Browning Reaction Prepared from Glucosamine. Japan Journal of Nutrition, 44, 307-315. https://doi.org/10.5264/eiyogakuzashi.44.307

[14] Olabinri, B., Adebisi, J., Odesomi, F., Olabinri, F. and Adeleke, E. (2010) Experimental Classification of the Antioxidant Capacity of the Leaf, Stem and Root Barks of Mangifera indica and Azadirachta indica. African Journal of. Biotechnology, 8 , 2968-2972.

[15] OECD (2008) Lignes directrices de l'OCDE pour les essais de produits chimiques № 425 Toxicité orale aiguë-Méthode de l'ajustement des doses. OECD, 1-29.

[16] Olton and Samuelson (1976) 8-Arm Radial Labyrinth Protocol. Neurology, 40, 269-272.

[17] Morris, J., McKeel, D., Storandt, M., Rubin, E., Price, L. and Grant, E. (1991) Very Mild Alzheimer's Disease: Informant-Based Clinical, Psychometric, and Pathologic Distinction from Normal Aging. Neurology, 41, 469-478.

https://doi.org/10.1212/WNL.41.4.469 
[18] Yagi, K. (1976) Simple Fluorometric Assay for Lipoperoxyde in Blood Plasma. Biology and Medicine, 15, 212-216. https://doi.org/10.1016/0006-2944(76)90049-1

[19] Gornall, A., Gomez-Caravaca, A., Gomez-Romero, M., Arraez-Roman, D., Segura-Carretero, A., Barwill, G. and David, M. (1949) Determination of Serum Protein by Eanms of the Buiret Reaction. The Journal of Biological Chemistry, 177, 751-766.

[20] Ellman, G. (1959) Quantitative Determination of Peptide by Sulfhydryl (-SH) Groups. Archives of Biochemistry and Biophysics, 82, 70-77. https://doi.org/10.1016/0003-9861(59)90090-6

[21] Ellman, G., Courtney, K., Andres, V. and Featherstone, R. (1961) A New and Rapid Colorimetric Determination of Acetylcholinesterase Activity. Biochemical Pharmacology, 7, 88-95. https://doi.org/10.1016/0006-2952(61)90145-9

[22] Sinha, K. (1972) Colorimetric Assay of Catalase. Analytical Biochemistry, 47, 389-394. https://doi.org/10.1016/0003-2697(72)90132-7

[23] Sun, Y., Oberley, L.W. and Li, Y.A. (1998) Simple Method for Clinical Assay of Superoxide Dismutase. Clinical Chemistry, 34, 479-500.

https://doi.org/10.1093/clinchem/34.3.497

[24] Montgomery, H. and Doymock, J. (1961) Colorimetric Determination of Nitric Oxide. Analyst, 86, 414. https://doi.org/10.1039/an9618600748

[25] Bouba, A., Njintang, Y., Scher, N. and Mbofung, F. (2010) Phenolic Compounds and Radical Scavenging Potential of Twenty Cameroonian Spices. Agriculture and Biology Journal of North America, 1, 213-224. https://doi.org/10.5251/abjna.2010.1.3.213.224

[26] Dada, F., Oyeleye, S., Ogunsuyi, O., Olasehinde, T., Adefegha, S., Oboh, G. and Boligon, A. (2017) Phenolic Constituents and Modulatory Effects of Raffia Palm Leaf (Raphia hookeri) Extract on Carbohydrate Hydrolyzing Enzymes Linked to Type-2 Diabetes. Journal Traditional and Complementary Medicine, 7, 494-500. https://doi.org/10.1016/j.jtcme.2017.01.003

[27] Tremoccoldi, M., Rosalen, P., Marcelo, F., Adna, M., Carina, P., Erica, D., Jonas, R. and Rizzato Priscilla, A. (2018) Exploration of Avocado By-Products as Natural Sources of Bioactive Compounds. PLoS ONE, 13, e0192577. https://doi.org/10.1371/journal.pone.0192577

[28] Shan, B., Yizhong, Z., Mei, S. and Harold, C. (2005) Antioxidant Capacity of 26 Spice Extracts and Characterization of Their Phenolic Constituents. Journal of Agricultural and Food Chemistry, 53, 7749-7759. https://doi.org/10.1021/jf051513y

[29] D’abrosca, D., Pacifico, S., Cefarelli, G., Mastellone, C. and Fiorentino, A. (2007) "Limoncella" Apple an Italian Apple Cultivar Phenolic and Flavonid Contents and Antioxidant Activity. Food Chemistry, 104, 1333-1337. https://doi.org/10.1016/j.foodchem.2007.01.073

[30] Oluyori, P., Dada, A. and Inyinbor, A. (2018) Phytochemical Analysis and Antioxidant Potential of Raphia hookeri Leaf and Epicarp. International Research Journal of Pure and Applied Chemistry, 34, 157-164. https://doi.org/10.13005/ojc/340608

[31] Siddhuraju, P. and Becker, K. (2007) The Antioxidant and Free Radical Scavenging Activities of Processedcowpea (Vigna unguiculata (L.) Walp) Seed Extracts. Food Chemistry, 101, 10-19. https://doi.org/10.1016/j.foodchem.2006.01.004

[32] Prashar, Y., Gill, N. and Perween, A. (2014) Protective Effect of Lagenaria siceraria in Reversing Aluminium Chloride Induced Learning and Memory Deficits in Experimental Animal Model. International Journal of Recent Advances in Pharmaceutical Research, 4, 87-104. 
[33] Al-Hashem, F., Dallak, N., Bashir, M. and Abbas, R. (2009) Camel's Milk Protects against Cadmium Chloride Induced Toxicity in White Albino Rats. American Journal of Pharmacology and Toxicology, 4, 107-117. https://doi.org/10.3844/ajptsp.2009.107.117

[34] Yokel, R. and Mcnamara, P. (1989) Elevated Aluminum Persists in Serum and Tissue of Rabbits after a Six-Hour Infusion. Toxicology and Applied Pharmacology, 99, 133-138. https://doi.org/10.1016/0041-008X(89)90118-X

[35] Al-Olayan, E.M., El-Khadragy, M.F. and Abdel Moneim, A.E. (2015) The Protective Properties of Melatonin against Aluminium-Induced Neuronal Injury. International Journal of Experimental Pathology, 96, 196-202. https://doi.org/10.1111/iep.12122

[36] Yao, J., Leonard, K. and Reddy, S. (2004) Increased Nitric Oxide Radicals in Postmortem Brain from Patients with Schizophrenia. Schizophrenia Bulletin, 30, 923-934. https://doi.org/10.1093/oxfordjournals.schbul.a007142

[37] Viezelienea, D., Beekhof, P., Gremmer, E., Rodovicius, H., Sadauskienea, I., Jansen, E. and Leonid, I. (2013) Selective Induction of IL-6 by Aluminum-Induced Oxidative Stress Can Be Prevented by Selenium. Journal of Trace Elements in Medicine and Biology, 27, 226-229. https://doi.org/10.1016/j.jtemb.2012.11.001

[38] Bihaqi, S., Sharma, M., Singh, A. and Tiwari, M. (2009) Neuroprotective Role of Convolvulus pluricaulis on Aluminium Induced Neurotoxicity in Rat Brain. Journal of Ethnopharmacology, 124, 409-415. https://doi.org/10.1016/j.jep.2009.05.038

[39] Esposito, E., Rotilio, D., Di Matteo, V., Di Giulio, C., Cacchio, M. and Algeri, S. (2012) A Review of Specific Dietary Antioxidants and the Effects on Biochemical Mechanisms Related to Neurodegenerative Processes. Neurobiology of Aging, 23, 719-735. https://doi.org/10.1016/S0197-4580(02)00078-7

[40] Kumar, S. (1998) Biphasic Effect of Aluminium on Cholinergic Enzyme of Rat Brain. Neuroscience Letters, 248, 121-123. https://doi.org/10.1016/S0304-3940(98)00267-5

[41] Kaizer, R., Correa, R. Spanevello, V., Morsch, C., Mazzanti, J., Goncalves and Schetinger, M. (2005) Acetylcholinesterase Activation and Enhanced Lipid Peroxidation after Long-Term Exposure to Low Levels of Aluminum on Different Mouse Brain Regions. Journal of Inorganic Biochemistry, 99, 1865-1870.

https://doi.org/10.1016/j.jinorgbio.2005.06.015 